Snežana Radukić ${ }^{1}$

P. $9-18$

Marija Petrović-Ranđelović ${ }^{2}$

Zorana Kostić

ORIGINAL SCIENTIFIC ARTICLE

University of Niš

Received: May, 15, 2019

Faculty of Economics

Accepted: June, 20, 2019

\title{
SUSTAINABILITY-BASED GOALS AND AND ACHIEVED RESULTS IN WESTERN BALKAN COUNTRIES ${ }^{4}$
}

\begin{abstract}
Agreed upon by the United Nations, the seventeen Sustainable Development Goals (SDGs) set out a framework to tackle the world's most pressing social, economic, and environmental challenges in the lead-up to 2030. They provide a network to support business in managing risks and identifying market opportunities. The Sustainable Development Goals have the potential to accelerate innovation and economic growth. However, the ambitious goals will require new models of collaboration between companies, sectors, countries, and regions. The special attention in this paper is given to the analysis of the achieved results in the Western Balkan countries in 2018 measured by the composite indicator such as Sustainable Development Goals Index. The basic research question in the research is: Are all the Western Balkans countries lagging behind the average of the region Eastern Europe and Central Asia in achieving the sustainable development goals?
\end{abstract}

Key words: sustainable development goals, index, Western Balkan countries

JEL classification: $Q 53$

\section{ЦИЉЕВИ ОДРЖИВОГ РАЗВОЈА И ОСТВАРЕНИ РЕЗУЛТАТИ У ЗЕМЉАМА ЗАПАДНОГ БАЛКАНА}

\section{Апстракт}

Договорени од стране Уједињених начија, седамнаест ичиьева одржсивог развоја (СДГс) поставило је оквир за решавање најзначајнијих друштвених, економских и еколошких изазова до 2030. године. Они пружају мрежу подршке пословној заједници приликом управљања ризицима и идентификоваға тржишних прилика. Циљеви одрживог развоја имају потенщијал да убрзају иноваџије и економски раст. Међутим, амбициозни цฺиљеви одрживог развоја ће

\footnotetext{
${ }^{1}$ snezana.radukic@eknfak.ni.ac.rs

${ }^{2}$ marija.petrovic-randjelovic@eknfak.ni.ac.rs

${ }^{3}$ zoksinis@gmail.com

${ }^{4}$ The paper is part of the Project No. 179066 and No. 44007 funded by the Ministry of Education, Science, and Technological Development of the Republic of Serbia.
} 
захтевати нове моделе сарадње између компанија, сектора, држава и региона.

Посебна пажњ у у овом раду посвецена је анализи постигнутих резултата у земљама Западног Балкана у 2018. години мерено композитним индикатором као што је Сустаинабле Девелопмент Гоалс Индех. Основно истраживачко питање од којег се пошло приликом истраживања гласи: Да ли све земле Западног Балкана заостају за просеком региона Источна Европа и Централна Азија у погледу остварених ичиљева одрживог развоја?

Кључне речи: цииљеви одрживог развоја, индекс, земље Западног Балкана

\section{Introduction}

Recognizing the fact that achieving the SDGs and harnessing the potential they represent is beyond the reach of any single company, the ambitions of the goals need coordination and collective efforts from entire sectors, countries and regions. Therefore, it is critical that leading companies and countries are able to develop detailed "roadmaps" to sustainable development in line with the SDGs.

In the context of sustainable development policy analysis indicators are useful in identifying trends and drawing attention to particular issues. They can also be helpful in setting policy priorities and in benchmarking or monitoring performance. The sustainable development index, as composite indicator, is formed in order to comply individual indicators into a single variable and to measure multidimensional concept which cannot be captured by a single indicator (Joint Research Centre-European Commission, 2008).

Basically, there are comprehensive alternatives to business that would help to change the course towards more coherent policies for sustainable development aligned with human rights principles and standards. It is important to recognize that the current problems of growing inequalities, unsustainable production and consumption are deeply connected with power hierarchies, institutions, culture and politics. Future actions and reforms which are necessary can be summarized in the following clusters (Civil Society Reflection Group on the 2030 Agenda for Sustainable Development, 2018):

- Turning the commitment to policy coherence into practice;

- Strengthening public finance at all levels;

- Improving regulation for sustainability and human rights;

- Better use or creation of new legal instruments;

- $\quad$ Refining measures and indicators of sustainable development;

- Closing global governance gaps and strengthening the institutional framework for sustainable development.

"The sustainable development strategy process offers an opportunity to build on the complementarities of programmes in the economic, environmental and social spheres to improve the longterm effectiveness of government policy agendas. Greater attention should be paid to the content of national sustainable development strategies (policy dimensions, timeframes, analytical tools), governance aspects (institutions, stakeholders, local links), and the processes for improving them (indicators, targets, monitoring). There is no single method, specific entry point or ideal co-ordinating 
mechanism for these strategies, which will reflect the economic, social, environmental and cultural specificities of countries" (Organisation for Economic Co-operation and Development, 2006).

The paper proceeds as follows. In the next section, we present and discuss the sustainable development policy and goals in the context of 2030 Agenda. The third section summarises the available empirical evidence bearing upon the sustainable development goals index in Western Balkan Countries. Finally, we emphasize the target values for each sustainable development goal by 2030 and give concluding remarks.

\section{The Sustainable Development Policy and Goals in the Context of 2030 Agenda}

The European Union (EU) is one of the leading global players in international development. Therefore, a key part of the EU's Multiannual Financial Framework (MFF) is the one reserved for action beyond EU's borders. This budget heading is called 'Global Europe' (also referred to as Heading IV). Under the current budget for the period of 2014 to 2020 , over 90 billion euros are available for the external action. The lion's share of this is reserved for development cooperation. The EU has dealt with new challenges in external action mostly by creating specific initiatives and new financial instruments. Heading IV thus appears to be rather complex and fragmented compared to other headings. They also represent a significant market opportunity for business, estimated to be worth at least US\$12 trillion per year by 2030 (WBCSD, 2018).

The 2030 Agenda and the sustainable development goals (SDGs) will provide the framework for future European Union development policy. While it will be equally challenging for European Union development policy and for the EU's overall external funding towards the implementation of the SDGs. Mainstreaming the sustainability principle within the geographic programmes Heading IV could ensure that overall the EU takes all three dimensions of sustainability into account. In addition, thematic allocations will gain in importance for the implementation of the 2030 Agenda as well as for a general focus on global public goods. Thematic allocations tend to be cross-country, more flexible and can mobilise funds for specific issue areas (Hackenesch et al., 2018).

The Sustainable Development Goals Report 2018 reviews progress in the third year of implementation of the 2030 Agenda for Sustainable Development. This part of the paper presents highlights of progress and remaining gaps for all 17 Sustainable Development Goals, based on the latest available United Nations data, and examines some of the interconnections across goals and targets.

Goal 1: End poverty in all its forms everywhere (Only 45 per cent of the world's population are covered by at least one social protection cash benefit)

Goal 2: End hunger, achieve food security and improved nutrition and promote sustainable agriculture (World hunger is on the rise again, Stunting, wasting and overweight still affected millions of children under age 5)

Goal 3: Ensure healthy lives and promote well-being for all at all ages (Births attended by skilled health personnel increased globally) 
Goal 4: Ensure inclusive and equitable quality education and promote lifelong learning opportunities for all (More than half of children and adolescents are not achieving minimum proficiency in reading and mathematics)

Goal 5: Achieve gender equality and empower all women and girls (Women spend about three times as many hours in unpaid domestic and care work as men)

Goal 6: Ensure availability and sustainable management of water and sanitation for all (3 in 10 people lack access to safely managed drinking water service, 6 in 10 people lack access to safely managed sanitation facilities)

Goal 7: Ensure access to affordable, reliable, sustainable and modern energy for all (4 in 10 people still lack access to clean cooking fuels and technologies)

Goal 8: Promote sustained, inclusive and sustainable economic growth, full and productive employment and decent work for all (Earning inequalities are still pervasive: men earned 12.5 per cent more than women, Youth were three times more likely to be unemployed than adults)

Goal 9: Build resilient infrastructure, promote inclusive and sustainable industrialization and foster innovation (Global carbon intensity decreased by 19 per cent between 2000 and 2015)

Goal 10: Reduce inequality within and among countries (Remittances to low- and middle-income countries represented over 75 per cent of total global remittances)

Goal 11: Make cities and human settlements inclusive, safe, resilient and sustainable (Damage to housing due to natural disasters showed a statistically significant rise)

Goal 12: Ensure sustainable consumption and production patterns (Globally by 2018, 108 countries had national policies on sustainable consumption and production, 93 per cent of the world's 250 largest companies are now reporting on sustainability)

Goal 13: Take urgent action to combat climate change and its impacts (The majority of countries have ratified the Paris Agreement and provided nationally determined contributions)

Goal 14: Conserve and sustainably use the oceans, seas and marine resources for sustainable development (Open ocean sites show current levels of acidity have increased by 26 per cent since the start of the Industrial Revolution)

Goal 15: Protect, restore and promote sustainable use of terrestrial ecosystems, sustainably manage forests, combat desertification, and halt and reverse land degradation and halt biodiversity loss (Land degradation threatens the security and development of all countries, The Red List Index shows alarming trend in biodiversity decline for mammals, birds, amphibians, corals and cycads)

Goal 16: Promote peaceful and inclusive societies for sustainable development, provide access to justice for all and build effective, accountable and inclusive institutions at all levels (Proportion of prisoners held in detention without sentencing has remained almost constant in the last decade, Globally, 73 per cent of children under 5 have had their births registered)

Goal 17: Strengthen the means of implementation and revitalize the Global Partnership for Sustainable Development.

Securing a strong and well-resourced Heading IV under the next MFF ultimately depends on the role and place of development policy vis-à-vis other EU policies. The way forward is to promote a strong EU development policy. This relates to the long-term and multi-dimensional nature of sustainable development, the adherence to fundamental values as well as to key principles of aid effectiveness, and implies a move away from the EU's current damage control mode (Hackenesch et al., 2018). 


\section{The Sustainable Development Goals Index in Western Balkan Countries}

In order to compute a global sustainable development measure, many researcheres uses composite index with an effort to summarise the goals stated in the SDGs. This indicator permits summarising complex and multi-dimensional realities to support decision-makers, it is easier to interpret than abroad range of different indicators, enables country comparison and country evolution assessment over time, and facilitates communication with the general public (Nhemachena et al., 2018, \& Hogan et al., 2018).

The Sustainable Development Goals are at the center of the global political agenda to eradicate extreme poverty, achieve universal education, promote gender equality and ensure environmental sustainability between others. They include areas such as economic inequality, environmental sustainability, innovation, peace and justice, sustainable consumption, among other priorities. These goals are organised in 169 indicators, which give an accurate perspective on the main dimensions related with country sustainable development. To gain insight into the relative position of involved countries, it is necessary to develop a composite index that summarises the global progress in the achievement of these goals, but considering possible conflicts and trade-offs between individual goals (Guijarro, \& Poyatos, 2018).

Table 1: Graph: The Sustainable Development Goals Index 2018 in Western Balkan countries

\begin{tabular}{|l|c|c|}
\hline \multicolumn{1}{|c|}{ Country } & Index Score & $\begin{array}{c}\text { SDGs Global } \\
\text { Rank (of 156) }\end{array}$ \\
\hline Albania & 68,9 & 62 \\
\hline Bosnia and Herzegovina & 67,3 & 71 \\
\hline FYRepublic of Macedonia & 69 & 61 \\
\hline Montenegro & 67,6 & 69 \\
\hline Serbia & 72,1 & 40 \\
\hline
\end{tabular}

Source: Authors according to Sachs et al., 2018.

Serbia has achieved the best results in achieving the goals of sustainable development. In addition, Serbia is the only one Wester Balkan country that has achieved better results than the regional average (Eastern Europe and Central Asia). It is worth mentioning that regional average score for Eastern Europe and Central Asia was 69,5 in 2018.

The Graph 1 gives an overview of the achieved results by individual goals and by country in 2018. Albania has the best results in achieving end poverty and ensure availability and sustainable management of water and sanitation for all. Also, Bosnia and Herzegovina achieves significant results on this issues, but achieves significant results in reducing inequality and combating climate change. It is characteristic for FYRepublic of Macedonia that considerable attention is paid to ensure healthy lives, promote well-being, ensure inclusive and equitable quality education, and promote lifelong learning opportunities for all. Montenegro's priority goals are those related to end poverty, availability and sustainable management of water and sanitation, and inclusive and equitable quality education as well as promote lifelong learning opportunities for all. Serbia has the best total score among selected countries, but the 
best results have been achieved in the next fields: end poverty, inclusive and equitable quality education, sustainable management of water and sanitation for all, sustainable cities and communities and combat climate change and its impacts. In order to emphasize the integrated approach to the concept of sustainability, some authors have considered the key economic and ecological indicators and the need for the coordination of the economic and environmental policy (Stojanović, Radukić, \& Kostić, 2015).

Some recent research has focused on the composition of a global sustainable development goals index to summarise the performance of each country regarding the achievement of the goals, considering that some of them are in conflict with others (Guijarro, \& Poyatos, 2018; Luukkanen et al., 2015).
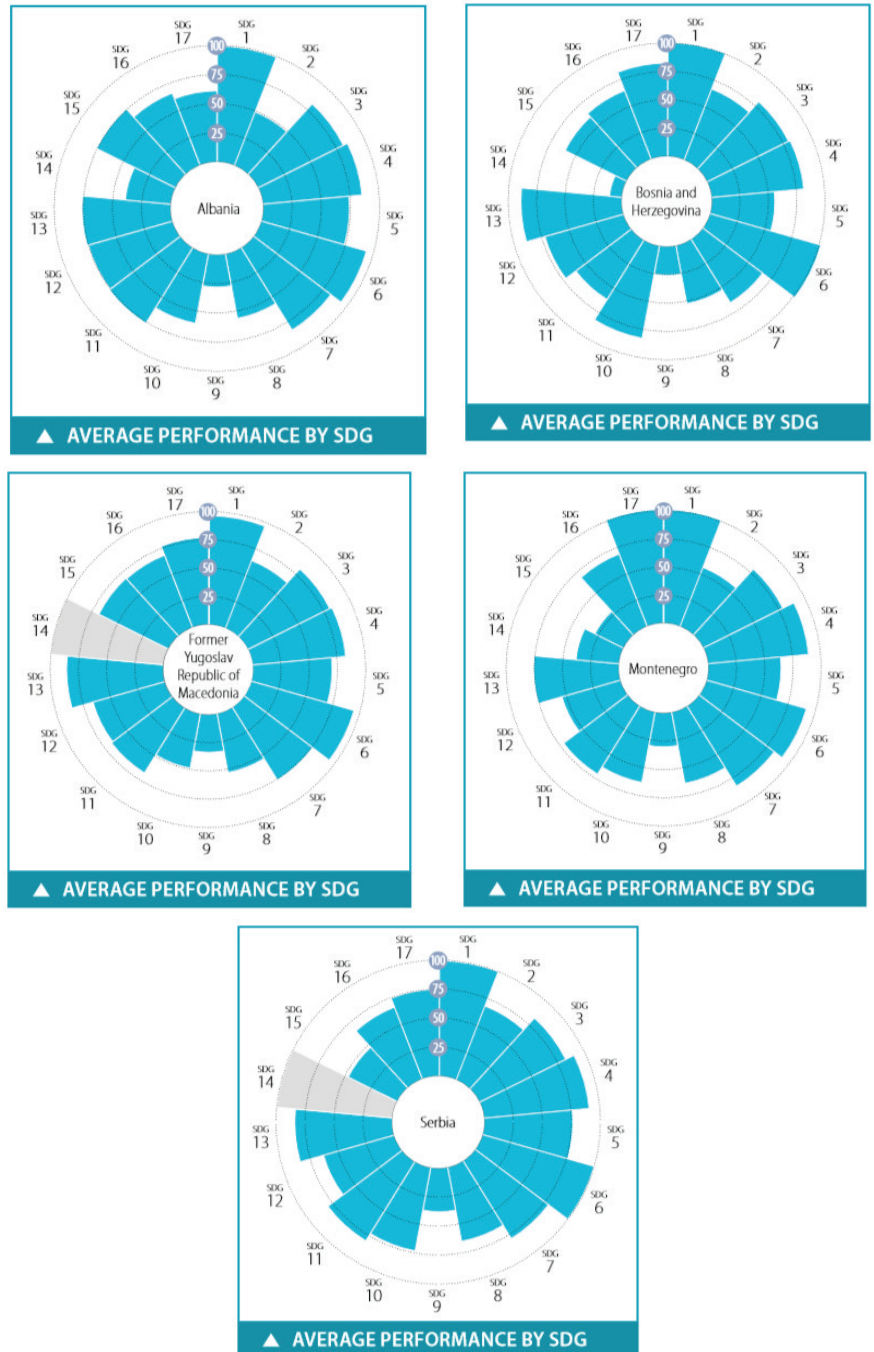

Graph 1: The Sustainable Development Goals Index 2018, by country Source: Sachs et al., 2018. 
Sustainable development has long been a central policy objective for the European Union. Achieved results and monitoring report on progress towards the SDGs in an EU context is periodically presented by Eurostat. The indicator set comprises 100 indicators and is structured along the 17 SDGs. For each SDG, it focuses on aspects which are relevant from an EU perspective. The indicator trends are described on the basis of a set of specific quantitative rules (Eurostat, 2018).

"Environmental constraints to rapid economic growth are increasingly recognized by countries, leading to a rising awareness of the need for sustainable development. Implementation of an environmental policy, however, generates significant implications for competition among countries" (Stojanović, \& Radukić, 2006, p. 471).

\section{Concluding remarks}

The implementation of the 2030 Agenda is not just a matter of better policies. The effectiveness of the required policy reforms in the implementation process requires more holistic and more sweeping shifts in how and where power is vested, and it depends on the existence of strong public institutions at national and international levels. The sustainable development goals define priorities and aspirations to mobilise global efforts among governments, business and civil society.

Respecting the goals, we emphasize the target values for each of them individually: (World Bank Group, 2018).

Goal 1: By 2030, eradicate extreme poverty for all people everywhere, currently measured as people living on less than $\$ 1.25$ a day and reduce at least by half the proportion of men, women and children of all ages living in poverty in all its dimensions according to national definitions.

Goal 2: By 2030, ensure sustainable food production systems and implement resilient agricultural practices that increase productivity and production, that help maintain ecosystems, that strengthen capacity for adaptation to climate change, extreme weather, drought, flooding and other disasters and that progressively improve land and soil quality.

Goal 3: By 2030, reduce the global maternal mortality ratio to less than 70 per 100,000 live births and by 2020, halve the number of global deaths and injuries from road traffic accidents.

Goal 4: By 2030, ensure that all girls and boys complete free, equitable and quality primary and secondary education leading to relevant and effective learning outcomes. By 2030, substantially increase the supply of qualified teachers, including through international cooperation for teacher training.

Goal 5: End all forms of discrimination against all women and girls everywhere and enhance the use of enabling technology, in particular information and communications technology, to promote the empowerment of women.

Goal 6: By 2030, achieve universal and equitable access to safe and affordable drinking water for all. Support and strengthen the participation of local communities in improving water and sanitation management.

Goal 7: By 2030, ensure universal access to affordable, reliable and modern energy services, increase substantially the share of renewable energy in the global energy mix, and double the global rate of improvement in energy efficiency. 
Goal 8: Sustain per capita economic growth in accordance with national circumstances and, in particular, at least 7 percent gross domestic product growth per annum in the least developed countries. Achieve higher levels of economic productivity through diversification, technological upgrading and innovation, including through a focus on high- value added and labour- intensive sectors.

Goal 9: Develop quality, reliable, sustainable and resilient infrastructure, including regional and transborder infrastructure, to support economic development and human well- being, with a focus on affordable and equitable access for all. Promote inclusive and sustainable industrialization and, by 2030, significantly raise industry's share of employment and gross domestic product, in line with national circumstances, and double its share in least developed countries.

Goal 10: By 2030, progressively achieve and sustain income growth of the bottom 40 percent of the population at a rate higher than the national average. Ensure equal opportunity and reduce inequalities of outcome, including by eliminating discriminatory laws, policies and practices and promoting appropriate legislation, policies and action in this regard.

Goal 11: By 2030, enhance inclusive and sustainable urbanization and capacity for participatory, integrated and sustainable human settlement planning and management in all countries.

Goal 12: Implement the 10- Year Framework of Programmes on Sustainable Consumption and Production Patterns, all countries taking action, with developed countries taking the lead, taking into account the development and capabilities of developing countries. By 2030, achieve the sustainable management and efficient use of natural resources.

Goal 13: Strengthen resilience and adaptive capacity to climate- related hazards and natural disasters in all countries. Integrate climate change measures into national policies, strategies and planning.

Goal 14: By 2025, prevent and significantly reduce marine pollution of all kinds, in particular from land- based activities, including marine debris and nutrient pollution.

Goal 15: Mobilize and significantly increase financial resources from all sources to conserve and sustainably use biodiversity and ecosystems.

Goal 16: Strengthen relevant national institutions, including through international cooperation, for building capacity at all levels, in particular in developing countries, to prevent violence and combat terrorism and crime.

Goal 17: Strengthen domestic resource mobilization, including through international support to developing countries, to improve domestic capacity for tax and other revenue collection.

As global business faces new and complex challenges and opportunities, sciencebased approach for the realization of the Sustainable Development Goals needs systems transformation. The main research results show that not all countries are lagging behind the average of the region Eastern Europe and Central Asia in achieving the sustainable development goals. In addition, Serbia is the only one Wester Balkan country that has achieved better results than the regional average.

Albania has the best results in achieving end poverty and ensure availability and sustainable management of water and sanitation. Bosnia and Herzegovina achieves significant results in reducing inequality and combating climate change. It is characteristic for FYRepublic of Macedonia that considerable attention is paid to ensure healthy lives, promote well-being, ensure inclusive and equitable quality education, and promote lifelong learning 
opportunities for all. Montenegro's priority goals are those related to end poverty, availability and sustainable management of water and sanitation, and inclusive and equitable quality education as well as promote lifelong learning opportunities for all. Serbia has the best total score among selected countries. Namely, the significant progress has been achieved in the next fields: end poverty, inclusive and equitable quality education, sustainable management of water and sanitation for all, sustainable cities and communities and combat climate change and its impacts.

In closing, it is important to state that while the sustainable development goals are well-grounded in theory, the economic reality of the Western Balkan countries shows that there is still a lot of continued effort in the long run for their achievement. Data unavailability for some of the SDGs indicators in some countries presented a limitation to the research and future efforts should focus on collecting data for the other countries in order to permit a wider application.

\section{References}

Civil Society Reflection Group on the 2030 Agenda for Sustainable Development (2018). Spotlight on Sustainable Development 2018, Exploring new policy pathways How to overcome obstacles and contradictions in the implementation of the 2030 Agenda Report.

Eurostat. (2018). Sustainable Development in the European Union: Monitoring Report On Progress Towards the SDGs in an EU Context. Luxemburg: Publications Office of the European Union.

Guijarro, F., \& Poyatos, J. (2018). Designing a sustainable development goal index through a goal programming model: The Case of EU-28 Countries. Sustainability, 10(9), 3167. DOI:10.3390/su10093167.

Hackenesch, C., Bergmann, J., Keijzer, N. \& Koch, S. (2018). EU budget reform: Opportunities and challenges for global sustainable development (Briefing Paper 4/2018). Bonn: German Development Institute / Deutsches Institut für Entwicklungspolitik (DIE). DOI: 10.23661/bp4.2018.

Hogan, D. R., Stevens, G. A., Hosseinpoor, A. R., \& Boerma, T. (2018). Monitoring universal health coverage within the Sustainable Development Goals: development and baseline data for an index of essential health services. The Lancet Global Health, 6(2), e152-e168. DOI: 10.1016/S2214-109X(17)30472-2

Joint Research Centre-European Commission. (2008). Handbook on constructing composite indicators: methodology and user guide. OECD publishing.

Luukkanen, J., Kaivo-oja, J., Vehmas, J., Panula-Ontto, J., \& Häyhä, L. (2015). Dynamic Sustainability. Sustainability Window Analysis of Chinese Poverty-Environment Nexus Development. Sustainability, 7(11), 14488-14500. DOI:10.3390/su71114488.

Nhemachena, C., Matchaya, G., Nhemachena, C., Karuaihe, S., Muchara, B., \& Nhlengethwa, S. (2018). Measuring baseline agriculture-related sustainable development goals index for Southern Africa. Sustainability, 10(3), 849. DOI:10.3390/su10030849. 
Organisation for Economic Co-operation and Development. (2006). Sustainable Development Studies: Good Practices in the National Sustainable Development Strategies of OECD Countries.

Petrović-Ranđelović, M., Radukić, S., \& Kostić, Z. (2018). Foreign direct investment, economic sovereignty and technology transfer in the context of sustainable development. Economics of Sustainable Development, Vol.2. pp. 1-10.

Sachs, J., Schmidt-Traub, G., Kroll, C., Lafortune, G., Fuller, G. (2018). SDG Index and Dashboards Report 2018. New York: Bertelsmann Stiftung and Sustainable Development Solutions Network (SDSN).

Stojanović, B., \& Radukić, S. (2006). EU Environmental Policy and Competitiveness. Panoeconomicus, 53(4), 471-485.

Stojanović B., Radukić, S., \& Kostić, Z. (2015). Level of sustainable development in the Republic of Serbia in the context of economic and environmental indicators. Regionalni razvoj i demografski tokovi zemalja jugoistočne Evrope, Faculty of Economics, University od Niš, pp. 51-60.

United Nations. (2018). The Sustainable Development Goals Report 2018. New York.

WBCSD. (2018) https://www.wbcsd.org/Programs/People/Sustainable-DevelopmentGoals/SDG-Action-Policy.

World Bank Group. (2018). Atlas of Sustainable Development Goals 2018 from World Development Indicators. Washington, DC 20433. DOI: 10.1596/978-1-46481250 . 